\title{
China's Growing Urban Health Inequalities: The Challenges Ahead
}

\author{
Ian G. Cook ${ }^{1}$, GU Chaolin ${ }^{2} \&$ Jamie Halsall ${ }^{3}$ \\ ${ }^{1}$ School of Humanities and Social Science, Liverpool John Moores University, Liverpool, UK \\ ${ }^{2}$ School of Architecture, Tsinghua University, Beijing, China \\ ${ }^{3}$ School of Human and Health Sciences, The University of Huddersfield, Queensgate, Huddersfield, UK \\ Correspondence: Jamie Halsall, School of Human and Health Sciences, The University of Huddersfield, \\ Queensgate, Huddersfield, UK. E-mail: j.p.halsall@hud.ac.uk
}

$\begin{array}{ll}\text { Received: October 26, } 2012 & \text { Accepted: November 30, } 2012 \quad \text { Online Published: February 26, } 2013 \\ \text { doi:10.5539/jms.v3n2p10 } & \text { URL: http://dx.doi.org/10.5539/jms.v3n2p10 }\end{array}$

\begin{abstract}
China is undergoing a rapid transformation from a rural, peasant based society into an urban one. This radical change has had a profound effect on the Chinese population due to advancement through job opportunities and new modes of consumption, contributing to a huge spatial shift of population from countryside to city. This effect on China's urban growth has resulted in a rise in the middle classes and in wealth. However this urban growth generates a number of key health issues and inequities, which present challenges for the future. The purpose of this paper is to explore these health issues and challenges that China's urbanization growth poses. The policyimplications will be significant.
\end{abstract}

Keywords: China, environmental, health, urbanization

\section{Introduction}

The physical growth of an urban area is termed urbanization and this growth has social implications. Kingsley Davis, the well respected American sociologist, concluded that urbanization occurs by rural-urban migration. Other possible influences, such as differential birth and mortality rates cannot be ignored and must be taken into consideration in population demography terms (Davies, 1972). This urbanization process refers to the relative concentrationof a territory's population in a town or city. In historical terms the process of urbanization has caused problems in many cities because as Herbert (1972, p. 25) argues urbanization is the result of the process of urbanization itself, 'by which the world is progressively becoming a more urban society with the shift from more rural and agricultural forms of living.' This spatial change is also acknowledged by other scholars in the field (Ma $\& W u, 2005$; Bachmann and Leung, 2008).Moreover, since the 1970s, studies on urbanization in the developing world have shifted towards the political economy (Castells, 1977; Gilbert \&Gugler, 1981). This is not surprising because a key feature of urbanization is industrialization. According to Johnston (1971, p. 19) both urbanization and industrialization are closely associated:

"Although it is possible for cities to develop without industries and for industries to exist outside cities, nevertheless the degree of population concentrated into urban centres is generally very closely associated with levels of economic development."

One country in the contemporary world where urbanization is a key challenge, in relation to the above, is China and in recent years the study of China's urbanization has generated much interest (Liu, 2005; Friedman 2006; Lin, 2007; Watson, 2009; Lin et al., 2011; Guet al., 2012; Wu 2012). The close proximity of urbanization and industrialization, in a conceptual context, is associated with the Chinese government's belief that urbanization and industrialization are intrinsically linked with the evolution of a developing, modernising nation (Cook, 2006). Basing its analysis on a case study of China, this paper firstly develops a conceptual understanding of China's urbanization. The paper then discusses the health challenges, such as environmental pressures on resources of air, water and land, and the growing inequities in health within China's cities. Sociospatial stratification is on the increase within these burgeoning cities and means that some parts of cities are more likely to suffer from 'diseases of affluence' such as hypertension or cancers while others are more likely to be affected by 'diseases of poverty' such as aresurgence of polio or tuberculosis. Further, China's cities are thought of as being young and dynamic, but one paradox of their demographic composition is that they are also the location for an increasing number of older people and Shanghai for example, is now considered to be a city of the aged (Cook \& Powell, 2007). There is also 
the question of the 'liudongrenkou' (floating population) to consider, because this large group of migrants is vulnerable to a range of health threats, and can become a source for a range of infections for the host society.

\section{Pace and Scale of Chinese Urbanisation}

Friedman (2003) notes that there has been a huge amount of research on China's cities. In the past the main focus on China's cities has been on coastal, geographical locations because cities such as Shanghai and Guangzhou have experienced exceptional economic growth. Blecher (1988) argued that urbanization in China is unprecedented, due to the transformation brought about by a society's shift from a rural to an urban society. This fundamental shift of populations moving from rural to urban centres can primarily be attributed to economic globalization. Scholars, such as, Yusuf and Wu (2002), Nolan (2004) and Wu (2006) have noted that this economic globalization has had a profound effect on China's urbanization. When analysing China's urbanization there are four distinct phases of expansion. Lin (2002) has identified these stages as: (1) initial growth of cities and urbanization (1949-1961); (2) reduction of cities and de-urbanization (1962-1965); (3) stagnation and under-urbanization (1966 -1977) and (4) accelerated growth and rapid urbanization (1978 - to present). See Table 1 for the urban population change over time.

Table 1. China's urban population, 1958-2008

\begin{tabular}{lll}
\hline Year & Urban Population \% & Urban Population Millions \\
\hline 1953 & 13.3 & 77.3 \\
1964 & 18.3 & 127.1 \\
1978 & 17.9 & 172.5 \\
1980 & 19.4 & 191.4 \\
1985 & 23.7 & 250.9 \\
1990 & 26.4 & 302.0 \\
1995 & 29.0 & 351.7 \\
2000 & 36.2 & 459.1 \\
2004 & 41.2 & 542.8 \\
2006 & 42.0 & 559.2 \\
2008 & 44.9 & 593.8 \\
2010 & 49.7 & 665.6 \\
\hline
\end{tabular}

Source: Adapted from: Cook, 2008, p.134; National Bureau of Statistics of China, 2009, First Report for the Sixth NationalSixth National Population Survey (No. 1) 2010 published by the National Bureau of Statistics in 2011,URL: http://zhidao.baidu.com/question/263485017.html?an=0\&si=5.

Fluctuations over time have included the changes during and following the Great Leap Forward (GLF) of 1958. The GLF strategy promoted a move to the countryside, but after the famines in its aftermath many migrated back to the cities. This alarmed the authorities who then once more restricted urban growth (Yang, 2008), and although urban-rural migration did continue (Kirby, 1985) this was offset by 'a disguised urbanization process caused by relatively fast demographic growth in urban areas' (Zhong\&Clarke, 1985). By the introduction of reform policies in the late 1970s and China opening trade to the outside world, population in urban areas in China had showed a steady but slow increase.

Since the beginning of the reform period in 1978 through to the present day there has been an accelerated growth in urbanization as Table 1 shows. This rapid change has come about due to market reforms and globalization and as Lin (2002, p. 306) confirms:

"The transition of power from Maoist plan ideological, into the post-Mao market-regulatory regime, has ushered in a new development strategy that values efficiency over equity, individual creativity over collectivism, and regional comparative advantages over decades or ideological considerations."

These reforms directed the Chinese government, in 1979, to create Special Economic Zones. Primarily this reform certified foreign investment and throughout the 1980s and 1990s the reform snowballed. For example since the early 1980s there have been special economic zones in Shenzhen, Zhuhai, Shantou, Xiamen and in 1984 development zones were further development zones were opened up in 14 coastal cities, including Dalian, Guangzhou, Ningbo, Qingdao, Shanghai and Tianjin, to overseas investment. According to Lin (2002, p. 306) from 1978 to 1984 the Chinese government commissioned 78 new cities and redeveloped 32 cities. The figure of cities increased from 193 in 1978 to 668 in 1998. Today, urbanization in China is now over the $50 \%$ level. This 
acceleration in population growth and urbanization can only be described as dramatic and this period has created new environmental and social challenges (Pannell, 2002). The World Health Organisation, with others (2010, p. IX) has recently noted that:

"Almost all urban population growth in the next 30 years will occur in cities of developing countries. Cities such as Phnom Penh, Cambodia; Tijuana, Mexico; Marrakesh, Morocco; and Lagos, Nigeria, are expected to grow at annual rates of around 4\%, effectively doubling their populations within the next 17 years. Some cities in China, such as Shenzhen and Xiamen, will experience annual growth rates of more than $10 \%$, doubling their populations roughly every seven years."

Further, and of relevance to health inequities, this rapid growth of China's urbanization, due to the changing economic system, has caused urban inequalities to grow. Longan (2008) has noted that the last two decades have created a culture of 'haves' and 'have nots' and there is a growing awareness of social inequalities. For example research undertaken by Liu and $\mathrm{Wu}$ (2006) has discovered that since the 1990s urban poverty has been a cause for concern. Liu and $\mathrm{Wu}(2006)$ have revealed that urban poverty occurs in specific locations. It has been suggested by $\mathrm{Wu}(2007)$ that the reason why urban poverty is seen to be problematic in urban China is directly linked to three major challenges which are: (1) deindustrialization (redundancy of state employment); (2) the change in the labour market and (3) public policies (housing privatization and minimum income support). Such contrasts in wealth underpin the health challenges that are facing China's cities today and tomorrow, and it is to these we now turn, beginning with the environmental threats in China's cities.

\section{The Environmental Threat to Urban Health}

China's urban environmental pressures can be attributed to the rapid growth of the city firstly as a centre of production and more recently as a centre of consumption (Gaoet al., 2001; Liuet al., 2003; Cook and Dummer, 2004), and gives rise to questions of environmental injustice that affect urban health. This environmental justice, in China's case, relates to three key areas which are threats to urban air, water and land. In contemporary urban China today these environmental challenges affect many millions of people in urban areas and affect mainly the poorest and most marginalized groups. In October 2005, for example, Beijing was recognized by the European Space Agency Satellite as being the most polluted city on earth while the World Bank states that 16 out of the world's most polluted cities are in China (Cook, 2007). This rise in poor air quality in Beijing can pose a threat to people in the city by producing the condition known colloquially as 'Beijing Throat'. Beijing Throat is developed through a lethal mixture of dust, vehicle pollution, industrial pollution and cloudy conditions.

More widely across China it has been estimated that 100 million people are living in cities where air quality conditions are perceived to be 'very dangerous' and 411,000 people have died prematurely from respiratory problems and heart disease. Walker (2006) has said that the biggest contributor to air pollution is coal burning and currently coal burning is at one tonne per head of population (around 1.3 billion tonnes) but future predictions suggest that this trend will increase to 2 billion tonnes by 2020. With this increase in coal burning in many Chinese cities acid rain has become a major problem, and as Gu and Cook (2011, p. 126) note, "poorer people are much more likely to have to put up with such conditions with detrimental effects on their health" because richer groups can move further away from pollution sources.

The second environmental challenge is water pollution. Research by Cook $(2007$, p.32) has argued that water pollution is a major concern and he warns:

"Seventy per cent of China's rivers and lakes are polluted so apart from the problem of rural water quality, even in the capital Beijing visitors are advised not to drink the tap water, and as in other countries there is a tremendous trade in bottled water in Beijing's supermarkets. This situation is found in many other cities too, while nearly two-thirds of China's cities, 420, are estimated to have water shortage problems, with 100 having 'acute shortage' including Beijing itself."

The reason why water is a problem is partly due to the legacy of the Maoist period's encouragement of heavy industry and economic growth. After Mao's death in 1976 the continued drive on China's heavy industry and economic growth created a disregard for the environmental impact, thus having an effect on the quality of water in many urban cities. An example of this concern is the ecological problem of the Yangtze River. However by 1998 the Chinese government decided to address this problem by building the first waste disposal plant in Chongqing (Cook \& Murray, 2001). The ever-increasing population growth within China's cities' has also placed pressure on water and created shortages. Cities expanding across China have placed a demand for greater amounts of water for industrial and personal use (e.g. toilets, showers and cooking). Walcott (2011, p. 84) shows that in Shanghai, the municipal authorities "continue to pour resources into the 'three coloured' types of environmental impacts: grey 
(chemical air quality); brown (sewage); and moving towards green (plantings to reduce heat and improve the ambient environment". But the long-term challenges still remain.

Finally, land pollution is the last major environmental challenge to Chinese cities. Again the reason why land pollution is deemed to be a threat is due to the heavy production industries such as chemical and steel. Steel and iron works such as Panzhihua have caused high levels of land pollution and as Shapiro (2001, p. 155) notes the Panzhihua Plant has resulted in 'enduring soil pollution by toxic metals which is not surprising in an environment in which chemicals and metals were so heavily and carelessly used.' This level of land pollution has created deforestation around the prefecture level city located in Sichuan Province. Moreover, the post-reform era land pollution still continues but has relatively improved. Murray and Cook (2004) have noted that China produces 9 million tons of waste every year but only manages disposal of a third of that amount safely. The Chinese government recognize that waste disposal has become a problem and realize that action needs to be taken to minimize urban environment threats, thus creating a better quality of life.

\section{China's Ageing Urban Population}

The rapid pace of change in urban China is throwing up some strange anomalies, not least that despite the overpowering imagery of cities being young and dynamic locations, many of them are becoming societies of the aged (Cook and Powell 2007; Cook and Halsall 2011). This is especially true of Shanghai and to a lesser extent Beijing and other cities on the Eastern seaboard. By Census 2000, China's aged population was $7 \%$ on average and over $9 \%$ in many coastal provinces, around $10-11 \%$ in many cities and over $15 \%$ in Shanghai. The pace of change is rapid and it may be that by $2100,27.1 \%$ of China's population will be in the elderly category (Cook and Powell 2005a, p.76), although the proportion may be more spatially even across the country as these higher numbers become characteristic of most parts of China. The challenge for China, as for many other societies, will be to ensure that older people are given the opportunity to maintain active healthy lives for as long as possible, receiving the level of support needed to ensure they have a high level of independence and security, while at the same supporting those who are vulnerable due to ill health, lack of family support, or poverty for example. This requires debate involving older people themselves and effective partnerships with a range of governmental, non-governmental and private sector agencies and companies. There will be a need to continually question the concept of dependency and also the role of the dominant bio-medical model in order to combat stereotypes of ageing and the desire for the authorities to 'take control' of the ageing body. As Cook and Powell show, however, the dependency idea is difficult to shake off in China, perhaps especially because of the legacy of the Single Child Family Programme that although it has in practice been more of a 1.5 child programme, means that in many cities there are relatively few children below 15 compared to many grandparents above 60 or 65 .

In an analysis of Beijing's demographic change, for example, Chen (2006) shows that numbers of children have fallen by 238,000 in five years while the number of people over 65 has risen to nearly 1.7 million, 10.8 per cent of the city's total population. It would seem that every 100 working people are supporting 13 children and 14 seniors. Older people are often seen as vulnerable by officials (Zhang, 2002), and although many are indeed vulnerable, others are not. This is an ageist construction that underpins an ageist discourse common to many societies, and we argue that vulnerability is as likely to be a product of such variables as gender, income and ethnicity rather than age per se.

Of course we acknowledge that it is certainly prudent to ensure that resources are available for one's retirement age, but it begs the question as to who exactly should pay for this. Deng Xiaoping sought to 'smash the iron rice bowl' of welfare available for former employees of State-Owned Enterprises (SOEs). Today, welfare support rests upon a 'multi pillar' approach (Williamson \&Deitelbaum 2005) with the pillars being an individual contribution of 8 per cent to mandatory individual accounts plus 20 per cent employer contribution to the first pillar in a PAYGO DB scheme (pay-as-you-go defined benefit). However this system, introduced in 2000, while laudatory in some aspects has not been easy to develop (ibid.), not least because of China's relatively underdeveloped financial markets, which are not yet best placed to handle large scale pension funds. The system is largely a product of the neoliberal policies around the globe, heavily influenced by networks of foreign 'experts' based in the Cato Institute of the United States for example. The outcome has been the development of a system that is more likely to benefit the better-off, leaving such groups as unmarried women, low-waged workers, and those who with 'irregular' work histories due to mental health and other problems vulnerable (ibid, p. 268). In this important analysis, Williamson and Deitelbaum outline and discuss three alternatives to this system from other countries such as Sweden or Italy, alternatives that are likely to offer greater protection from market fluctuations of the type that has just been seen in the global recession. 
In terms of social discourse the emphasis on foreign-expert-driven neoliberal economic policies dovetails neatly with the dominance of the biomedical model of ageing that overemphasizes the body as a site for technocratic solutions to ageing, ranging from ameliorative drug provision through cosmetic surgery to full replacement of body parts by organic or mechanical alternatives. As shown by Powell and Cook (2000) and Cook and Powell (2005b), the urban environment is a significant factor in the ageing process, offering potential for alternative discourses to the master narratives of inevitable decay and decline of the ageing body. One significant element of policy, for example, rests on the recovery of Confucian ideals of respect for older people, and the PRC government has sought to re-emphasize such traditions in recent years, partly via awareness-raising and partly via legislation. Some of the latter has an interventionist dimension that would prove unacceptable in other societies, for instance the 'Law on the Rights and Interests of the Elderly' promulgated in late 1996 that requires families to offer financial support to their elderly parents, with the latter having the right to take their children to court in order to force adequate payments for their welfare (Cook \&Halsall, 2011). More acceptable outside China would be the view of Zhang Kaiti, vice-director of the China Research Center on Aging, who suggests that the elderly now have 'higher and more special demands in their lives. First, they have to be out in society and that will help them not to be lonely. Second, children should return to see their parents often and communicate with them regularly. This is what is best for the elderly' (cited in Cook and Powell, 2007). 'Someone to talk to' and assistance from the community when they had to go out is what many older people would prefer, and Zhang suggested that costs of providing this service and that of a medical service, life service and volunteer service is low but it could have a better all round effect via creation of a better environment for older people at an insignificant economic cost.

Chen and Chen (2009) review the concept of 'active ag(e)ing' in a wide range of Chinese policy documents. They note that while much is made of the word 'active' (jiji) the concept has 'tended to be used in a conventional way to describe such specific aspects as participation and more frequently in describing governmental and societal work rather than individual lifestyle' (Chen \& Chen, 2009, p. 77; Cook \&Halsall, 2011). In contrast, active ag(e)ing (jijilaolinghua) 'has not been adopted or incorporated in a majority of the policy instruments...to any notable extent (if at all)' (ibid, p. 75). Although there is a growing interest in the concept in China, the association between active ageing and encouragement of individual independence has proved problematic for policy makers, and is indeed a 'thorny subject' for them (ibid, p. 84).

Following on from Moody's (1998) notion that some see older people as divided into the 'wellderly' and the 'illderly' and that 'successful ageing' is essentially about 'surviving' in urban spaces, Cook and Powell (2007) argue that the overemphasis on age as a single variable is overly reductionist, and that conversely, age is primarily a social constructed problem and 'the symptomatic deep manifestation of underlying relations of power and inequality that cuts across and through age, class, gender, disability and sexuality' (Cook \& Powell 2005a, p.81). This means that in China, following Moody, 'some elderly will not only be 'illderly' or 'wellderly,' but 'poorderly,' 'richderly,' 'femderly,' 'malederly,' 'Handerly' or 'nonHanderly' for example' (Cook \& Powell, 2007). The urban authorities will increasingly be required to grapple with this complexity of categorization in order to target resources more effectively and efficiently towards those that are most in need of support, those who are most vulnerable due to combinations of poverty, gender inequalities, ethnicity, mental ill health and location. In contrast, many older people, as in other societies will require little in support because they are better-off, healthier in physical and mental terms; have advantages of good family support and so on. As argued before, the approach will have to be pointillistic rather than broad brush, avoiding stereotypes of ageing while recognizing that specific older people do indeed need and deserve wider support from society, recognizing that in the face of rapid change, 'China's elderly are not mere victims in a sea of turbulence; rather they are themselves an intrinsic part of this changing environment of the contemporary 'Middle Kingdom'” (Powell \& Cook, 2006).

\section{China's Growing Urban Underclass}

With the increase in wealth of the middle classes, combined with foreign tourism and the growth of the liudongrenkou or floating population, has come the return of large-scale criminal activities, including the return of prostitution in China's cities. Historically, concubines and prostitutes were common in ancient China; in part reflecting the gender and power inequalities of the patriarchal Confucian system. Under communism in the Maoist period prostitutes were regarded as 'life's dust'; re-education of the type noted above would be used to reform those who were prostitutes and prostitution all but disappeared until the Reform Period of recent decades in which when the door is opened 'a few flies fly in,' as Deng Xiaoping put it. Often prostitutes provide a service for the male migrants of the 'floating population,' ensuring that STDs have increased in recent years, giving rise to at-risk populations of prostitutes and non-prostitutes alike (Xia, 2004). It is clear that a greater sense of cultural permissiveness means that sexual behavior is now more widespread across different groups. This increases risk, therefore, and although current policies to reduce HIV spread, for example, have had a certain level of success 
these must nonetheless be scaled up and improved to meet the potential scale of this particular health problem (Rou et.al. 2010).

In terms of migrants, Cook and Dummer (2007) and Zhang (2007) have discussed the vulnerability of migrants to a range of health problems, including alcoholism, lung cancer via high rates of cigarette smoking, STDs and HIV/AIDS. It is not just males that are vulnerable; for example 'female migrants have been found to have very high rates of smoking (Chen, et.al. 2004), linked inevitably to economic, social and cultural stresses associated with their urban lives' (Cook and Dummer, 2007, p. 224). Zhang (2007) notes, however, that we must be careful not to 'demonise' the floating population who can be subject to considerable prejudice from the host urban society. Policy must ensure that this group as well as sex workers are approached sensitively, and that they receive appropriate health information and advice as to preventative measures such as condom use that can reduce the risk of infection. Further, the link between migration and changing cultural norms must also be better understood. Smith and Hugo (2008, p. 309), for example, show that 'migration is only one of many variables that have interwoven to produce totally new sets of risk factors' to STD spread.

Another feature of migrant life is their spatial concentration, into 'urban villages', that in many other countries would be squatter settlements, but in Beijing for example, the migrants live in the same areas as people from their own town or province, and rent in overcrowded conditions that can also be a health risk in themselves. Gu in a number of studies (see Gu et.al. 2006 or Gu\& Cook, 2011, for example) shows that migrants are subject to, and are a feature of, growing social polarization. The issue of denial of access to urban services, such as education and health care, with provision often 'rooted in the migrants' rural villages of origin' as Walcott, 2011, notes, remains one that the authorities will be required to tackle.

\section{Conclusion}

China's urbanisation is on the increase and is a key feature of the country's development strategy. Within China's expanding cities will be a range of health threats as the $21^{\text {st }}$ Century unfolds. These will include the so-called 'diseases of affluence' associated with wealth creation, but in tandem with these will be the 'diseases of poverty' that concentrate among China's growing urban underclass that includes many in the floating population (Cook \&Dummer, 2004). Policy makers and planners alike will be required to ensure that health prevention is tailored to the increasingly diverse groups that make up China's urban population. The marked growth in urban poverty and inequalities that is being increasingly documented in a number of studies will have a knock-on effect on health inequalities, which are closely linked to inequalities in wealth (Wu \& Webster, 2010). Growing diversity in the urban population means, however, that a catch-all policy approach will not work; what is needed is a sophisticated and focused policy that can deal with the specificities of China's urban health inequalities as the century unfolds. This means better information provision as to health inequities in cities and a targeted approach that meets the needs of the most vulnerable groups in Chinese urban society. Without such an approach, urban health inequalities will become more and more obvious as the $21^{\text {st }}$ Century unfolds.

\section{Acknowledgements}

This paper was originally presented at the two day international workshop: Culture, Sustainability and the Built Environment: Revisiting Heritage and Vernacular in Economic, the University of Kuwait. The authors are very grateful to Jason Powell, Peer Smets, Tasleem Shakur and Omar Khattabfor their insights at the planning and reviewing stage of this paper. Thanks also to Hazel Gee for her role as proof reader. Finally, the authors wish to acknowledge the comments from the reviewers.

\section{References}

Bachmann, J. K., \& Leung, A. S. P. (2008). Towns against a background of cities: recent evolution of town urbanization policy in the People's Republic of China. International Planning Studies, 13(1), 13-30. http://dx.doi.org/10.1080/13563470801969590

Castells, M. (1977). The Urban Question. London: Arnold.

Chen, S. (2006). Beijing has Fewer Children and More Seniors. Beijing Today, $24^{\text {th }}$ March.

Chen, S., \& Chen, E. Y. (2009). Active Aging and China: Perspectives and Issues. In Powell, J. L., \& Cook, I. G. (Eds.), Aging in Asia (chapter 4, pp. 67-88). New York: Nova Science Publishers.

Chen, X. G., Li, X. M., Stanton, B., Fang, X. Y., Lin, D. H., Cole, M., Liu, H. J., \& Yang, H. M. (2004). Cigarette smoking among rural-to-urban migrants in Beijing. Preventive Medicine, 39(4), 666-673. http://dx.doi.org/10.1016/j.ypmed.2004.02.033 
Cook, I. G. (2006). Beijing as an internationalized metropolis. In Wu, F. (Ed.), Globalizationand the Chinese City (chapter 4, pp. 63-84). London: Routledge.

Cook, I. G. (2007). Environmental, health and sustainability in twenty-first century China. In Sanders, R., \& Yang, C. (Eds.), China's Post Reform Economy: Achieving Harmony, Sustaining Growth (chapter 3, pp. 30-43). London: Routledge.

Cook, I. G. (2008). $21^{\text {st }}$ Century Issues and Challenges in Chinese Urbanization. In Wagner, W. N. (Ed.), Urbanization: $21^{\text {st }}$ Century Issues and Challenges (chapter 4, pp. 133-153). New York: Nova Science Publishers.

Cook, I. G., \& Dummer, T. J. B. (2004). Changing health in China: re-evaluating the epidemiological transition model. Health Policy, 67(3), 329-343. http://dx.doi.org/10.1016/j.healthpol.2003.07.005

Cook, I. G., \& Dummer, T. J. B. (2007). Spatial and social marginalisation of health in China: the impact of globalisation. In Zhang, H. X., Wu, B., \& Sanders, R. (Eds.), Marginalisation in China: Perspectives on Transition and Globalisation (chapter 12, pp. 215-237). Aldershot: Ashgate.

Cook, I. G., \& Halsall, J. P. (2011). Aging in Comparative Perspective: Processes and Policies. International Perspectives on Aging 1. New York: Springer.

Cook, I. G., \& Murray, G. (2001). China's Third Revolution: Tensions in the Transition to Post-Communism. London: Curzon.

Cook, I. G., \& Powell, J. L. (2005a). China, Aging and Social Policy: The Influences and Limitations of the Bio-Medical Paradigm. Journal of Societal and Social Policy, 4(2), 71-89.

Cook, I. G., \& Powell, J. L. (2005b). China and Ageing: The Influences of the Bio-Medical Paradigm on Population Discourse and Health Policy. Paper presented in the China Session: Continuity, transition and transcendence: urban development and reform in China (2), RGS/IBG Annual Conference, September, London.

Cook, I. G., \& Powell, J. L. (2007). Ageing Urban Society: Discourse and Policy. In Wu, F. (Ed.), China's Emerging Cities (chapter 7, pp. 126-142). London: Routledge.

Davis, K. (1972). World Urbanization 1950-1970. Institute of International Studies, Berkeley: University of California Press.

Friedman J. (2006). Four theses in the study of China's urbanization. International Journal of Urban and Regional Research, 30(3), 440-451. http://dx.doi.org/10.1111/j.1468-2427.2006.00671.x

Friedman, J. (2003). China's Urbanization. International Journal of Urban and Regional Research, 27(3), 745-758. http://dx.doi.org/10.1111/1468-2427.00480

Gao, J., Tang, S., Tolhurst, R., \& Rao, K. (2001). Changing access to health services in urban China: implications for equity. Health Policy and Planning, 16(3), 302-312. http://dx.doi.org/10.1093/heapol/16.3.302

Gilbert, A., \& Gugler, J. (1981). Cities, Poverty and Development. Oxford: Oxford University Press.

Gu, C., \& Cook, I. G. (2011). Beijing: socialist capital and new world city. In Hamnett, S., \& Forbes, D. (Eds.), Planning Asian Cities: Risks and Resilience (chapter 4, pp. 90-130).

Gu, C., Chan, R. C. K., Liu, J., \& Kesteloot, C. (2006). Beijing's socio-spatial restructuring: immigration and social transformation in the epoch of national economic reformation. Progress in Planning, 66(4), 249-310. http://dx.doi.org/10.1016/j.progress.2006.10.001

Gu, C., Wu, L., \& Cook, I. G. (2012). Progress in research on Chinese urbanization. Frontiers of Architectural Research, 1(2), 101-149.

Herbert, D. T. (1972). Urban Geography: A Social Perspective. Newton Abbot: David \& Charles.

Johnston, R. J. (1970). Urban Residential Patterns. London: Bell and Sons.

Kirby, R. J. R. (1985). Urbanisation in China: Town and Country in a Developing Economy. London: Croom Helm.

Lin, G. C. S. (2002). The Growth and Structural Change of Chinese Cities: A Contextual and Geographical Analysis. Cities, 19(5), 299-316. http://dx.doi.org/10.1016/S0264-2751(02)00039-2 
Lin, Y., Meulder, B., \& Wang, S. (2011). Understanding the 'Village in the City' in Guangzhou Economic Integration and Development Issues and their Implications for the Urban Migrant. Urban Studies, 48(16), 3583-3598.

Liu, E. (2005). The Architectural Fairyland of China (1984 onward): Problems and Recommendations. In Shakur, T. (Ed.), Cities in Transition: Transforming the Global Built Environment (part 5, pp. 191-200). Cheshire: Open House Press,

Liu, G. G., Wu, X., \& Peng, C. (2003). Urbanization and Health Care in Rural China. Contemporary Economic Policy, 21(1), 11-24. http://dx.doi.org/10.1093/cep/21.1.11

Liu, Y., \& Wu, F. W. (2006). Urban poverty neighbourhoods: typology and spatial concentration under China's market transition, a case study of Nanjing. Geoforum, 37(4), 610-626. http://dx.doi.org/10.1016/j.geoforum.2005.11.006

Ma, J. C., \& Wu, F. (2005). Restructuring the Chinese City: Changing Society, Economy and Space. London: Routledge.

Moody, H. R. (1998). Aging, Concepts and Controversies. Thousand Oaks: Pie Forge Press and Sage.

Murray, G., \& Cook, I. G. (2004). The Greening of China. Beijing: China Intercontinental Press.

National Bureau of Statistics of China. (2009). China Statistical Yearbook. Beijing: China Statistics Press.

Nolan, P. (2004). Transforming China: Globalization, Transition and Development. London: Anthem Press.

Pannell, C. W. (2002). China's continuing urban transition. Environment and Planning A, 34(9), 1571-1589. http://dx.doi.org/10.1068/a34201

Powell, J. P., \& Cook, I. G. (2000). A Tiger Behind and Coming Up Fast: Governmentality and the Politics of Population Control in China. Journal of Aging and Identity, 5(2), 79-89. http://dx.doi.org/10.1023/A:1009590620292

Powell, J. P., \& Cook, I. G. (2006). Unpacking Patriarchy: A Case Study of Patriarchy and the Elderly in China. International Journal of Sociology and Social Policy, 26(7/8), 277-283. http://dx.doi.org/10.1108/01443330610680371

Rou, K., Sullivan, S. G., Liu, P., \& Wu, Z. (2010). Scaling up prevention programmes to reduce the sexual transmission of HIV in China. International Journal of Epidemiology, 39, ii38-ii46. http://dx.doi.org/10.1093/ije/dyq211

Smith, C. J., \& Hugo, G. (2008). Migration, urbanization, and the spread of sexually transmitted diseases: empirical and theoretical observations in China and Indonesia. In Logan, J. R. (Ed.), Urban China in Transition (chapter 13, pp. 294-314). Oxford: Blackwell. http://dx.doi.org/10.1002/9780470712870.ch13

Walcott, S. (2011). The Dragon's Head: spatial development of Shanghai. In Hamnett, S., \& Forbes, D. (Eds.), Planning Asian Cities: Risks and Resilience (chapter 3, pp. 67-89).

Walker, M. (2006). A nation struggling to catch its breath. Newscientist, 190(2540), 8-9.

Watson, V. (2009). The planned city sweeps the poor away..., Urban planning and 21 st century urbanisation. Progress in Planning, 72(2), 151-193. http://dx.doi.org/10.1016/j.progress.2009.06.002

Williamson, J. B., \& Deitelbaum, C. (2005). Social Security Reform: Does Partial Privatisation Make Sense for China? Journal of Aging Studies, 19(2), 257-271. http://dx.doi.org/10.1016/j.jaging.2004.06.009

World Health Organization, The WHO Centre for Health Development Kobe, and United Nations Human Settlements Programme ((UN-HABITAT), 2010). Hidden Cities: Unmasking and Overcoming Health Inequities in Urban Setting. Geneva: WHO Press.

Wu, F. (2002). China's Changing Urban Governance in the Transition Towards a More Market-oriented Economy. Urban Studies, 39(7), 1071-1093. http://dx.doi.org/10.1080/00420980220135491

$\mathrm{Wu}, \mathrm{F}$. (2006). Globalization and the Chinese City. London: Routledge.

$\mathrm{Wu}, \mathrm{F}$. (2007). The poverty of transition: from industrial district to poor neighborhood in the city of Nanjong, China. Urban Studies, 44(13), 2673-2694. http://dx.doi.org/10.1080/00420980701558376

Wu, F. (2012). Neighborhood Attachment, Social Participation, and Willingness to Stay in China's Low-Income Communities. Urban Affairs Review, 48(4), 547-570. http://dx.doi.org/10.1177/1078087411436104 
Wu, F., \& Webster, C. (2010). Marginalization in Urban China: Comparative Perspectives. Basingstoke, Macmillian. http://dx.doi.org/10.1057/9780230299122

Xia, G. (2004). HIV/Aids in China. Beijing: Foreign Language Press.

Yang, D. T. (2008). China's Agricultural Crisis and Famine of 1959-1961: A Survey and Comparison to Soviet Famines. Comparative Economic Studies, 50(1), 1-29. http://dx.doi.org/10.1057/ces.2008.4

Yusuf, S., \& Wu, W. (2002). Pathways to a world city: Shanghai rising in an era of globalisation. Urban Studies, 39(7), 1213-1240. http://dx.doi.org/10.1080/00420980220135572

Zhang, B. (2002). Ageing Population Requires New Action. Retrieved October 17, 2005, from www.cpirc.org.cn/en/enews20020329.htm

Zhang, H., X. (2007). Conceptualising the links: migration, health and sustainable livelihoods in China. In Zhang, H. X., Wu, B., \& Sanders, R. (Eds.), Marginalisation in China: Perspectives on Transition and Globalisation (chapter 11, pp. 195-214). Aldershot: Ashgate.

Zhong, F. (2000). Urbanization. In Xizhe, P., \& Guo, Z. (Eds.), The Changing Population of China (chapter 13, pp. 167-178). Oxford: Blackwell.

Zhong, F., \& Clarke, J. (1985). Urban population growth in China: its characteristics and areal variations. $C R U$ Working Paper 26, University of Durham: Department of Geography. 